EISSN: 2706-7955 ISSN: 2077-4605

DOI: $10.36632 / \mathrm{mejar} / 2021.10 .3 .62$

Journal homepage: www.curresweb.com

Pages: 954-963

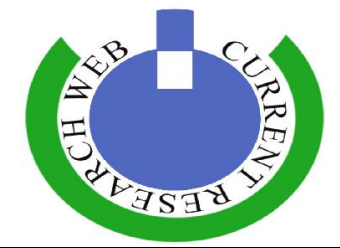

\title{
Evaluating the Yield Advantage of Using Rhizobium Inoculant in Improved Varieties of Soybean and Beans
}

\section{Otim Godfrey Anyoni ${ }^{1,2}$, Obong Samson ${ }^{1}$, Otim Bosco', Abdoulaye Fofana Fall ${ }^{2}$, Komakech Alfred ${ }^{3}$, Akuru Grace ${ }^{4}$ and Laban F. Turyagyenda ${ }^{1}$}

${ }^{1}$ Ngetta Zonal Agricultural Research and Development Institute, National Agricultural Research Organization, P. O. Box 295, Entebbe, Uganda.

${ }^{2}$ Uganda Martyrs University, P.O. Box 5498, Kampala, Uganda.

${ }^{3}$ Project for the Restoration of Livelihood in Northern Region, P.O Box 7037, Kampala, Uganda. ${ }^{4}$ Makerere University, P.O.Box 7062, Kampala

Received: 20 January $2021 \quad$ Accepted: 30 July $2021 \quad$ Published: 30 August 2021

\begin{abstract}
The on-farm average yield of soybean (Glycine max) and beans (Phaseolus vulgaris) are 1t/ha and $0.8 \mathrm{t} /$ ha respectively. This is nearly a third of the potential yield, which is attributed to a number of factors including poor nodulation with the native rhizobia available in the soil. This study was done to assess the yield advantage for inoculation of selected improved soybean and bean varieties with Bradyrhizobium japonicum and Rhizobium leguminosarum bv phaseoli respectively, on-station in lira and at five on-farm sites for two seasons. The study sites were located in the districts of Agago, Omoro, Kitgum, Amuru and Lamwo. The mother baby trial methodology was used to conduct participatory adaptive research. A randomized complete Block design was used for on-station trials. The trials included evaluating response of three improved inoculated and uninnoculated soybean and bean varieties in each commodity against a local check. Results showed significant differences $(p<0.05)$ for both inoculated improved soybean and bean varieties. Inoculation of improved bean varieties significantly $(\mathrm{p}<0.05)$ increased nodule numbers per plant, but was not significant for number of pods per plant. Also inoculation of improved soybean varieties significantly increased nodule numbers per plant, but was insignificant for number of pods per plant. Grain yield was also significantly $(p<0.05)$ higher in inoculated plots as compared to un-inoculated plots. Inoculation significantly increased yield in selected improved varieties in soybean and beans on average by $22.3 \%$ and $15 \%$, respectively. In soybean MAKSOY $1 \mathrm{~N}$, MAKSOY $5 \mathrm{~N}$, MAKSOY $3 \mathrm{~N}$ and LOCAL varieties were respectively improved by $14.13 \%, 23.33 \%, 64.40 \%$ and $42.8 \%$ compared to the non-inoculated controls. In beans NARO BEAN1, NARO BEAN2, NABE4 and LOCAL were respectively improved by $19.71 \%$, $14.50 \%, 7.84 \%$ and $16.27 \%$ compared to the non-inoculated controls. It can be concluded that MAKBIO-FIXER inoculum containing Bradyrhizobium japonicum and Rhizobium leguminosarum bv phaseoli as an efficient approach for improving the nodulation process and increasing grain legume yield for selected improved varieties in soybean and beans respectively. Therefore, the use of these inoculum to enhance yield in these varieties can be recommended.
\end{abstract}

Keywords: Bradyrhizobium japonicum, Glycine max, Phaseolus vulgaris, Rhizobium leguminosarum bv phaseoli, inoculation, nodulation.

\section{Introduction}

Grain legumes are a very important source of dietary proteins and oil for humans (Joint, 1998). Agriculture today faces challenges such as soil fertility loss, climate change and increased attacks from pathogens and pests. Grain legume yield among farmers in Northern agro-ecology zone was less than a third of potential yield (PRELNOR, 2017). This is similar to findings by (Tittonell and Giller, 2013).

Corresponding Author: Otim Godfrey Anyoni, Ngetta Zonal Agricultural Research and Development Institute, National Agricultural Research Organization, P. O. Box 295, Entebbe, Uganda.

E-mail: Otimgw@gmail.com 
There's need to increase grain legume yield to encourage its production by farmers as this will support sustainable agricultural production. Sustainable agricultural production is based on environmentally friendly approaches such as the use of biofertilizers, biopesticides and the return of crop residues (Mabrouk et al., 2018).

About $78 \%$ of the atmospheric air is N, this gaseous substance cannot be used in this form by most living organisms until it has been fixed, that is, reduced (combined with hydrogen) to ammonia. Biological nitrogen fixation (BNF) is one of the most 'environmentally friendly' approach for obtaining nitrogen in agro-ecosystems since BNF uses energy derived from photosynthesis and does not accumulate excess nitrogen to cause pollution (Jensen and Hauggaard-Nielsen, 2003). BNF offers substantial source of $\mathrm{N}$ in cropping system since atmospheric $\mathrm{N}_{2}$ is a renewable resource (Hungria and Bohrer, 2000) and accounts for $60 \%$ of nitrogen used in agriculture, lightening $10 \%$ and $25 \%$ from chemical fertilizers (Zahran, 1999). Grain legumes in addition to BNF contribute a significant input of $\mathrm{N}$ if vegetative legume residues are returned to the soil after grain harvest, thus offering potential benefit of subsequent cereal and other non-leguminous crops. Soybean has been reported to biologically fix nitrogen in the range of $85-154 \mathrm{~kg} \mathrm{~N} \mathrm{ha}^{-1}$ (Giller et al., 2011). These grain legume attributes are important for cropping-system sustainability and climate change resilience. However, grain legumes face challenges in southern African countries such as low seed viability, poor nodulation with native rhizobia available in the soil, low availability and awareness of inoculants, lack of some essential nutrients in the soil and lack of market information (Vidigal et al., 2019).

Rhizobium-legume symbiosis system is considered the most efficient and important process in crop production. It plays a role in sustaining long-term soil fertility in different agricultural systems (Amarger, 2001). Leguminous plants in partnership with Rhizobium have the ability to convert the atmospheric nitrogen into usable forms. The use of Rhizobium inoculation meets $50-70 \%$ of the crop nitrogen requirement and increases legumes productivity (Ndakidemi et al., 2006).

In Uganda farmers still find fertilizer costly, hence low usage at only $1.9 \mathrm{~kg} / \mathrm{ha}$ against a world average of $141 \mathrm{~kg} / \mathrm{ha}(\mathrm{FAO}, 2016)$. The requirements for Fertilizer-N are predicted to increase in the future, however the use of high doses of fertilizers has a negative and an unpredictable impact on the environment and contaminates the soil, water and other natural resources (Otieno et al., 2009 and Kanianska, 2016). It's well noted that yield limitation is a function of many factors, however, most farmers in Uganda usually grow soybean without applying inoculants. In Malawi grain yield in soybean inoculated with Bradyrhizobium japonicum was significantly higher in inoculated plots as compared to un-inoculated plots with ranges of 524 to $1868 \mathrm{~kg} \mathrm{ha}^{-1}$ for inoculated soybean and 246 to $905 \mathrm{~kg} \mathrm{ha}^{-1}$ for un-inoculated soybean (Njira et al., 2013). Currently, new varieties are being released for soybean and beans, but there's very little information available on their response to MAK-BIO-FIXER.

\section{Materials and Methods}

\subsection{Site and Research design / Methodology}

The mother baby trial methodology was used to conduct participatory adaptive research. The Mother-Baby methodology analyzes the average treatment effects of technologies when there is selfselection among host farmers and plots and substantial heterogeneity (Snapp et al., 2002). This methodology is essential in order to develop, asses and test various agronomic practices in a manner that incorporates diverse farmer priorities and can evaluate performance across a range of management pratices and edaphic conditions in a quantifiable and repeatable manner.

The central mother trial was replicated within the site at Ngetta Zonal Agricultural Research and Development Institute (NgeZARDI) in season 2019A and 2019B. NgeZARDI is located in northern Uganda at $02^{\circ} .29573^{\prime} \mathrm{N}$; $032^{\circ} .92092^{\prime} \mathrm{E}$; 1 , and at 101 meters above sea level (masl). Average daily temperature is $25^{\circ} \mathrm{C}$; while maximum temperature is $29^{\circ} \mathrm{C}$. The climate is moist, sub-humid, with a mean annual rainfall of $1,639.1 \mathrm{~mm}$ that is bi-modally distributed from March- June and AugustDecember (Kumakech et al., 2014). The design used for the on-station trial was a randomized complete Block design in split plot arrangement with two main plot treatments (inoculated and uninnoculated), each with four (4) sub plot treatments replicated three times i.e. NARO BEAN 1, 2, NABE 4 \& local check for beans and MAKSOY 1N, 3N, 5N\& Local check for Soy bean. This therefore presented two different studies for beans and soybean genotypes respectively. The baby trials are replicates of the mother trial. Five on farm trials were established in 2019A and 2019B each farmer's field representing 
a replicate. The replicates contained the different varieties for each of soybean and beans as subplot treatments, inoculated and uninnoculated as the main plot treatments.

Soybean trials were established in the districts of Agago, Omoro, Kitgum and Lamwo and beans in the districts of Lamwo, Amuru and Omoro. Table 1 shows sites soils characteristics. The on station main plots located in Lira district measured $19 \mathrm{~m} \times 31 \mathrm{~m}$ and subplots $5 \mathrm{mx} 5 \mathrm{~m}$ with interplot spacing of $1.5 \mathrm{~m}$ and interblock spacing of $2 \mathrm{~m}$. The beans were spaced at $50 \mathrm{~cm} \times 15 \mathrm{~cm}$ and soybean at $60 \mathrm{cmx}$ $10 \mathrm{~cm}$. On-farm plots measured $5 \times 5 \mathrm{~m}$ with similar crop spacing, inter plot and inter block spacing as on-station. Land preparation was done using hand hoe, weeding was done twice at 3weeks and 7weeks respectively. Harvesting was done at crop physiological maturity.

Table 1: Characteristic of soils

\begin{tabular}{ccccccccccl}
\hline & $\mathbf{p H}$ & $\mathbf{O M}$ & $\mathbf{P}$ & $\mathbf{C a}$ & $\mathbf{M g}$ & $\mathbf{K}$ & Sand & Clay & Silt & \multicolumn{1}{c}{ Textural } \\
Class
\end{tabular}

\subsection{Mineral fertilization}

All plots received triple superphosphate $\left(46 \% \mathrm{P}_{2} \mathrm{O}_{5}\right)$ during soil preparation at the rate of $100 \mathrm{~kg}$ $\mathrm{ha}^{-1}$, while muriate of potash $\left(60 \% \mathrm{~K}_{2} \mathrm{O}\right)$ was applied at the rate of $40 \mathrm{~kg} \mathrm{ha}^{-1}$. All treatments received ammonium nitrate $(34 \% \mathrm{~N})$ at a rate of $50 \mathrm{~kg} \mathrm{~N} \mathrm{ha}^{-1}$ at planting time as an activator dose.

\subsection{Inoculation method}

The MAK-BIO-N-FIXER inoculant containing Bradyrhizobium japonicum bacteria $\left(10^{6}\right.$ viable cell/g inoculum) for soybean and Rhizobium leguminosarum bv phaseoli $\left(10^{6}\right.$ viable cell/ $\mathrm{g}$ inoculum) for beans were used as a biological nitrogen fixer. The source of inoculant is Makerere University, Kampala. Inoculation process in both cases involved mixing 1 spoonful of sugar in $300 \mathrm{mls}$ of clean water ( 1 soda bottle) to form a $5 \%$ sugar solution inoculum sticker. $15 \mathrm{~kg}$ of Soybean / bean seeds was weighed and poured in a clean basin and then the inoculum sticker added to it. The inoculum sticker (slurry) of 1:1 ratio in 5\% sugar solution was mixed thoroughly with $15 \mathrm{~kg}$ seeds of soybean $/$ beans until each seed was evenly coated. The coated seed was covered with paper/cloth and left to dry in the shed for 30 minutes and planting done within 24 hours of inoculation.

\subsection{Plant sampling and analysis}

Plant sampling was done using systematic random sampling selecting after every 2 plants from within the net plot of eight ridges. 10 soybean/bean plants per subplot were sampled at poding stage, after data was collected from each of these plants on the following three parameters; number of pods, total number of nodules. Grain yield $(\mathrm{kg} / \mathrm{ha})$ was collected at physiological maturity. Total number of nodules per plant was collected through destructive sampling for nodule counts and nodule effectiveness at flowering according to standard procedures. 10 plants, two from each row was dug up, and uprooted from a net plot of $5 \mathrm{~m} \times 5 \mathrm{~m}$.

\subsection{Data Analysis}

Data collected were subjected to two-way Analysis of Variance (ANOVA) according to the procedures outlined by Snedecor and Cochran (1980) using Xlstat edition 2020. Separation of treatment means was done using least significant differences (LSD) at 0.05 level of probability. 


\section{Results}

\subsection{Effect of Bradyrhizobia inoculum on the performance of soybean}

Data presented in (Tables 2 and 3) (Fig.1, 2 and 3) show the response of number of pods per plant, total number of nodules per plant and grain yield $(\mathrm{kg} / \mathrm{ha})$ of soybean to Bradyrhizobium inoculation at harvest.

The number of pods is significantly higher in uninoculated soybean plants than in inoculated. There is no significant difference in the total number of nodules in inoculated soybean plants compared to uninoculated plants. On the other hand, the grain yield of the inoculated plants is significantly higher than those of the un-inoculated plants $(\mathrm{p}=0.0001<0.05)$ (Table 2). Rhizobial inoculation has a significant influence on grain yield. In non-inoculated plants the yield is $1360.00 \pm 30.70 \mathrm{~kg} \mathrm{ha}^{-1}$. It is $1663.33 \pm 32.90 \mathrm{~kg} \mathrm{ha}^{-1}$ in inoculated plants, an increase of $22.30 \%$ compared to uninoculated plants.

Furthermore, inoculation has no influence on the number of pods and the total number of nodules in the different varieties of soybean. However, the grain yield of the different varieties was significantly improved by inoculation $(\mathrm{p}=0.0001<0.05)$ (Table 3). The MAKSOY $1 \mathrm{~N}$, MAKSOY $5 \mathrm{~N}$, MAKSOY $3 \mathrm{~N}$ and LOCAL varieties were respectively improved by $14.13 \%, 23.33 \%, 64.40 \%$ and $42.8 \%$ compared to the non-inoculated controls.

Table 2: Number of pods per plant, total number of nodules per plant and grain yield $(\mathrm{kg} / \mathrm{ha})$ as influenced by Bradyrhizobium inoculation

\begin{tabular}{llll}
\hline Treatments & $\begin{array}{l}\text { Number of pods } \\
\text { (per plant) }\end{array}$ & $\begin{array}{l}\text { Total number of nodules } \\
\text { (per plant) }\end{array}$ & $\begin{array}{l}\text { Grain yield } \\
\text { (kg/ha) }\end{array}$ \\
\hline Uninoculated & $63.54 \pm 0.28 \mathrm{a}$ & $55.8 \pm 0.39 \mathrm{a}$ & $1360.00 \pm 30.70 \mathrm{~b}$ \\
Inoculated & $43.83 \pm 0.22 \mathrm{~b}$ & $65.04 \pm 0.48 \mathrm{a}$ & $1663.33 \pm 32.90 \mathrm{a}$ \\
\hline
\end{tabular}

In each column, values are expressed as mean \pm SE. Different letters within column indicate significant difference between treatments according to the Turkey test at $\mathrm{P}<0.05$

Table 3: Effects of Bradyrhizobium inoculation on number of pods per plant, total number of nodules per plant and grain yield $(\mathrm{kg} / \mathrm{ha})$ of four varieties of soybean.

\begin{tabular}{lllllll}
\hline & \multicolumn{2}{l}{ Number of pods (per plant) } & \multicolumn{2}{l}{ Total number of nodules (per plant) } & Grain yield (kg/ha) \\
\cline { 2 - 6 } Varieties & Uninoculated & Inoculated & Uninoculated & Inoculated & Uninoculated & Inoculated \\
\hline MAKSOY 1N & $58.53 \pm 0.91 \mathrm{a}$ & $34.43 \pm 0.65 \mathrm{~b}$ & $31.70 \pm 0.75 \mathrm{a}$ & $62.10 \pm 1.79 \mathrm{a}$ & $1226.67 \pm 12.57 \mathrm{~b}$ & $1400.00 \pm 21.77 \mathrm{a}$ \\
MAKSOY 5N & $75.70 \pm 0.96 \mathrm{a}$ & $32.37 \pm 0.58 \mathrm{~b}$ & $95.57 \pm 2.05 \mathrm{a}$ & $79.6 \pm 2.51 \mathrm{a}$ & $1600.00 \pm 32.66 \mathrm{~b}$ & $1973.33 \pm 35.00 \mathrm{a}$ \\
MAKSOY 3N & $65.90 \pm 1.49 \mathrm{a}$ & $65.40 \pm 1.16 \mathrm{~b}$ & $49.63 \pm 1.21 \mathrm{a}$ & $71.63 \pm 1.61 \mathrm{a}$ & $1773.33 \pm 12.57 \mathrm{~b}$ & $2880.00 \pm 37.71 \mathrm{a}$ \\
LOCAL & $55.03 \pm 0.85 \mathrm{a}$ & $43.13 \pm 0.57 \mathrm{~b}$ & $46.60 \pm 1.07 \mathrm{a}$ & $46.83 \pm 1.5 \mathrm{a}$ & $840.00 \pm 39.25 \mathrm{~b}$ & $1200.00 \pm 67.99 \mathrm{a}$ \\
\hline
\end{tabular}

In each row, values are expressed as mean \pm SE. Different letters within row indicate significant difference between treatments according to the Turkey test at $\mathrm{P}<0.05$

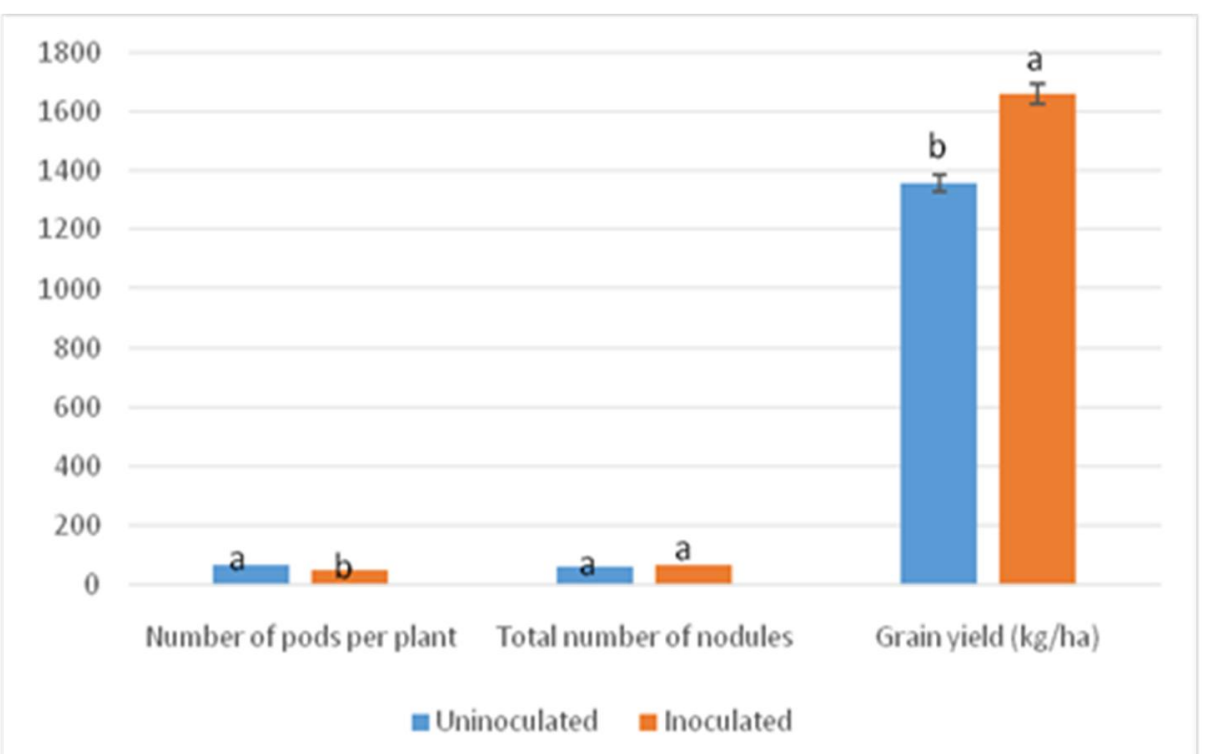

Fig. 1: Number of pods per plant, total number of nodules per plant and grain yield $(\mathrm{kg} / \mathrm{ha})$ as influenced by Bradyrhizobium inoculation 


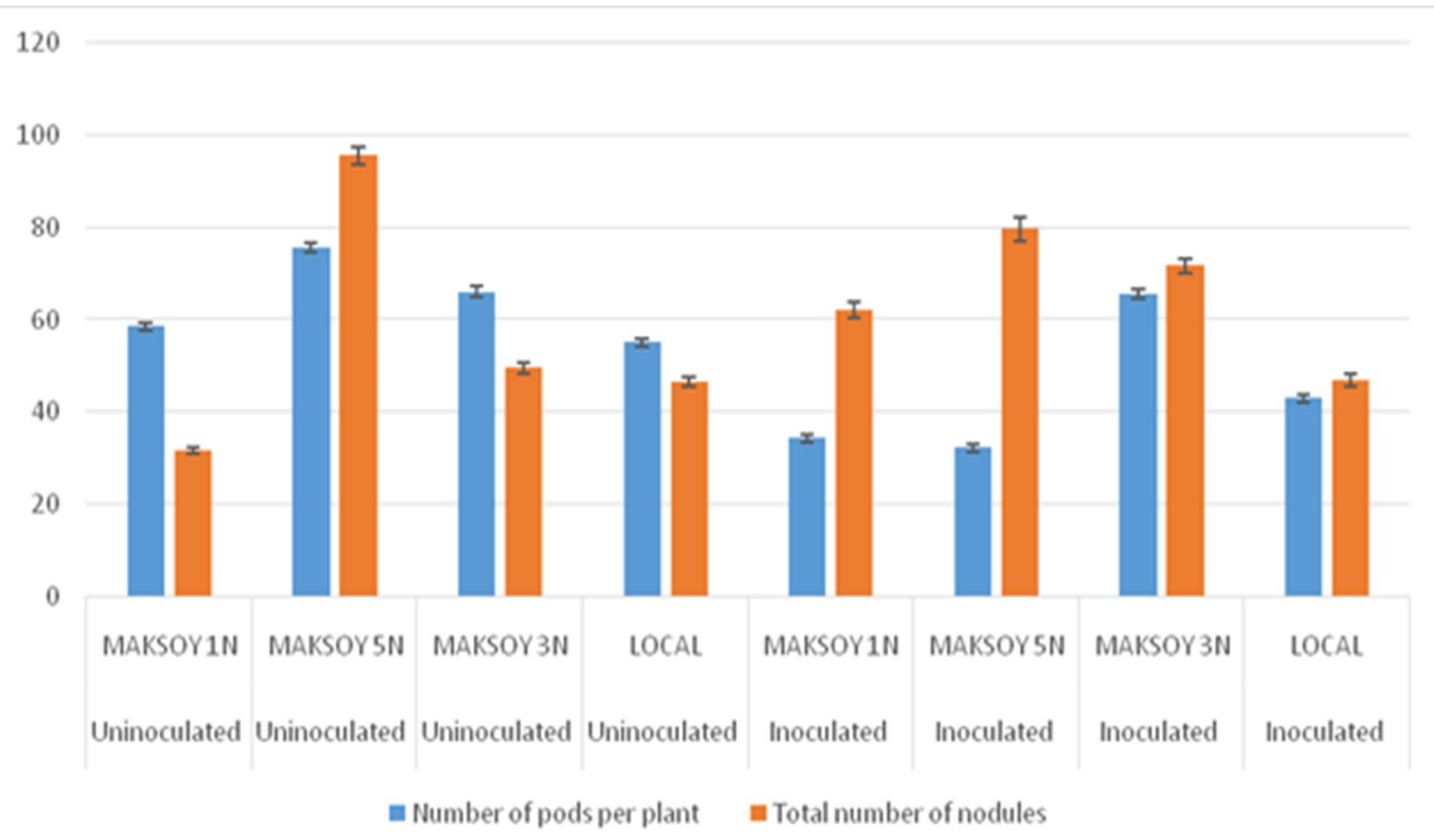

Fig. 2: Number of pods per plant and total number of nodules per plant as influenced by Bradyrhizobium inoculation

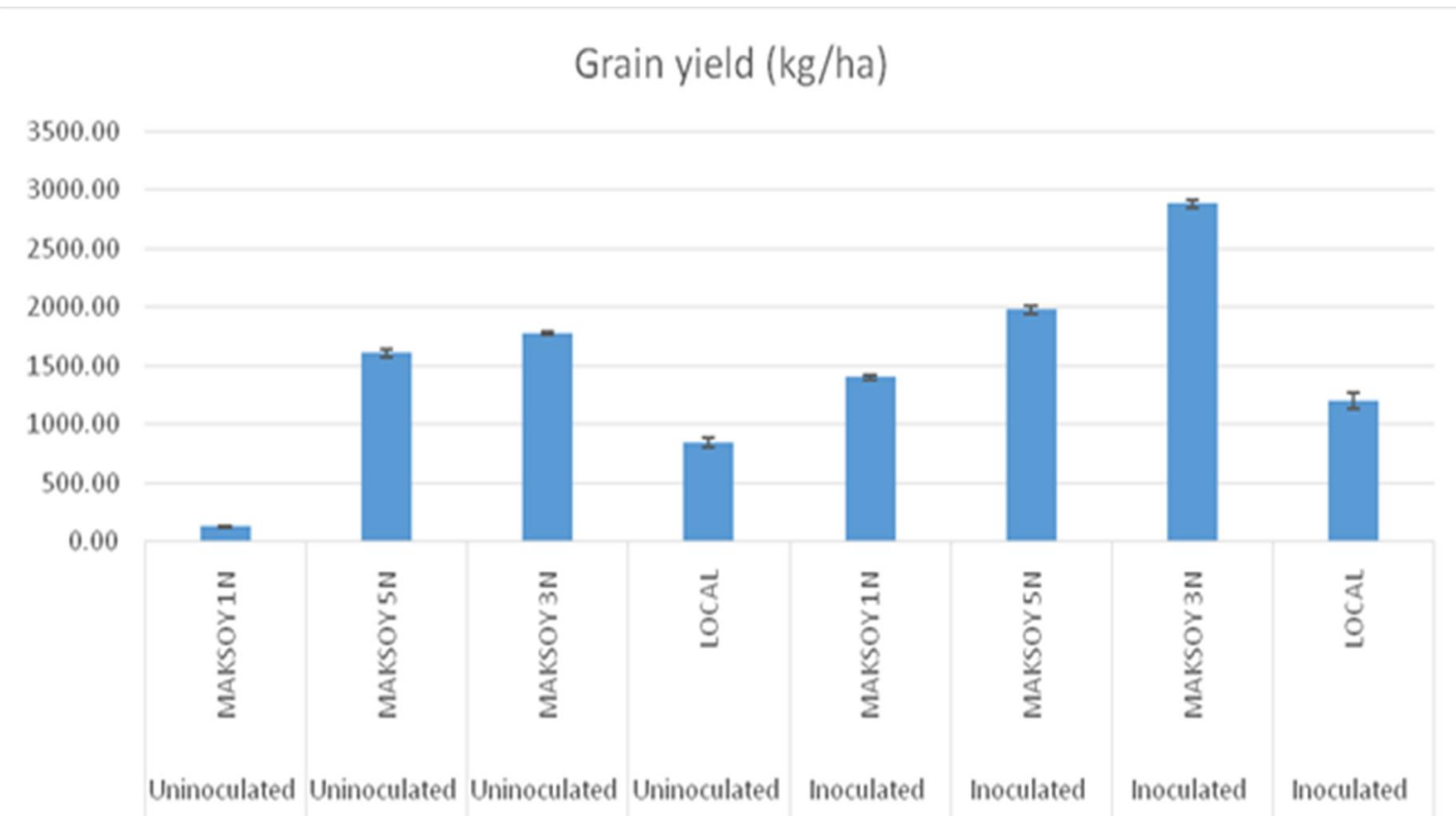

Fig. 3: Grain yield (kg/ha) as influenced by Bradyrhizobium inoculation

\section{Effect of Rhizobium leguminosarum bv phaseoli inoculum on the performance of beans}

Data presented in (Tables 4 and 5) (Fig. 4, 5 and 6) show the response of number of pods per plant, total number of nodules per plant and grain yield $(\mathrm{kg} / \mathrm{ha})$ of bean to Rhizobium leguminosarum $b v$ phaseoli inoculation at harvest. The number of pods is significantly higher in uninoculated bean plants than in inoculated ones. There was also significant difference in the total number of nodules in inoculated bean plants compared to uninoculated ones. In addition, the grain yield of inoculated plants was significantly higher than those of uninoculated plants $(p=0.0001<0.05)$ (Table 4). Rhizobial inoculation has a significant influence on grain yield. In the uninoculated plants the yield was 1536.67 $\pm 28.23 \mathrm{kgha}^{-1}$ while it was $1766.67 \pm 35.25 \mathrm{kgha}^{-1}$ in the inoculated plants, an increase of $14.96 \%$ compared to the uninoculated plants. Inoculation has no influence on the number of pods. However, 
inoculation had a significant influence on the number of nodules also grain yield of the different varieties was significantly improved by inoculation $(\mathrm{p}=0.0001<0.05)$ (Table 5$)$. The beans varieties NARO BEAN1, NARO BEAN2, NABE4 and LOCAL were respectively improved by $19.71 \%$, $14.50 \%, 7.84 \%$ and $16.27 \%$ compared to the non-inoculated controls.

Table 4: Number of pods per plant, total number of nodules per plant and grain yield ( $\mathrm{kg} / \mathrm{ha})$ as influenced by Rhizobium leguminosarum bv phaseoli inoculation

\begin{tabular}{llll}
\hline Treatments & $\begin{array}{l}\text { Number of pods } \\
\text { (per plant) }\end{array}$ & $\begin{array}{l}\text { Total number of nodules } \\
\text { (per plant) }\end{array}$ & $\begin{array}{l}\text { Grain yield } \\
\text { (kg/ha) }\end{array}$ \\
\hline Uninoculated & $27.48 \pm 0.14 \mathrm{a}$ & $55.47 \pm 0.53 \mathrm{~b}$ & $1536.67 \pm 28.23 \mathrm{~b}$ \\
Inoculated & $17.20 \pm 0.06 \mathrm{~b}$ & $106.16 \pm 0.44 \mathrm{a}$ & $1766 \pm 35.25 \mathrm{a}$ \\
\hline
\end{tabular}

In each column, values are expressed as mean \pm SE. Different letters within column indicate significant difference between treatments according to the Turkey test at $\mathrm{P}<0.05$

Table 5: Effects of Rhizobium leguminosarum bv phaseoli inoculation on number of pods per plant, total number of nodules per plant and grain yield $(\mathrm{kg} / \mathrm{ha})$ of four varieties of bean

\begin{tabular}{lllllll}
\hline & \multicolumn{2}{c}{$\begin{array}{c}\text { Number of pods } \\
\text { (per plant) }\end{array}$} & \multicolumn{2}{c}{$\begin{array}{c}\text { Total number of nodules } \\
\text { (per plant) }\end{array}$} & \multicolumn{2}{c}{$\begin{array}{c}\text { Grain yield } \\
\text { (kg/ha) }\end{array}$} \\
\cline { 2 - 7 } Variety & Uninoculated & Inoculated & Uninoculated & Inoculated & Uninoculated & Inoculated \\
\hline NAROBEAN1 & $20.37 \pm 0.32 \mathrm{a}$ & $19.20 \pm 0.19 \mathrm{~b}$ & $50.33 \pm 2.30 \mathrm{~b}$ & $116.33 \pm 1.65 \mathrm{a}$ & $1893.33 \pm 90.65 \mathrm{~b}$ & $2266.67 \pm 83.15 \mathrm{a}$ \\
NAROBEAN2 & $23.30 \pm 0.40 \mathrm{a}$ & $16.43 \pm 1.70 \mathrm{~b}$ & $30.03 \pm 1.43 \mathrm{~b}$ & $111.73 \pm 1.70 \mathrm{a}$ & $1746.67 \pm 35.00 \mathrm{~b}$ & $2000 \pm 54.43 \mathrm{a}$ \\
NABE4 & $22.83 \pm 0.37 \mathrm{a}$ & $15.53 \pm 1.52 \mathrm{~b}$ & $78.73 \pm 2.38 \mathrm{~b}$ & $91.90 \pm 1.52 \mathrm{a}$ & $1360.00 \pm 39.25 \mathrm{~b}$ & $1466.67 \pm 62.85 \mathrm{a}$ \\
LOCAL & $43.40 \pm 0.69 \mathrm{a}$ & $17.66 \pm 2.00 \mathrm{~b}$ & $62.77 \pm 1.90 \mathrm{~b}$ & $104.62 \pm 2.00 \mathrm{a}$ & $1146.67 \pm 25.14 \mathrm{~b}$ & $1333.33 \pm 31.43 \mathrm{a}$ \\
\hline
\end{tabular}

In each row, values are expressed as mean \pm SE. Different letters within row indicate significant difference between treatments according to the Turkey test at $\mathrm{P}<0.05$

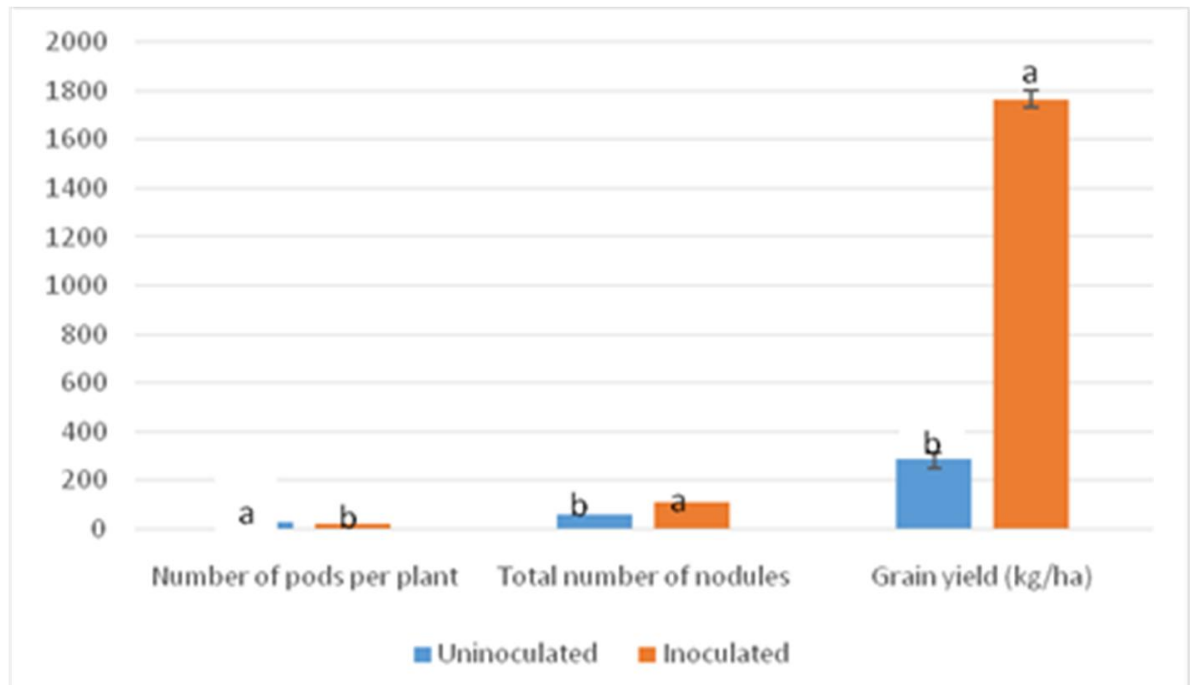

Fig. 4: Number of pods per plant, total number of nodules per plant and grain yield $(\mathrm{kg} / \mathrm{ha})$ as influenced by Rhizobium leguminosarum bv phaseoli inoculation 


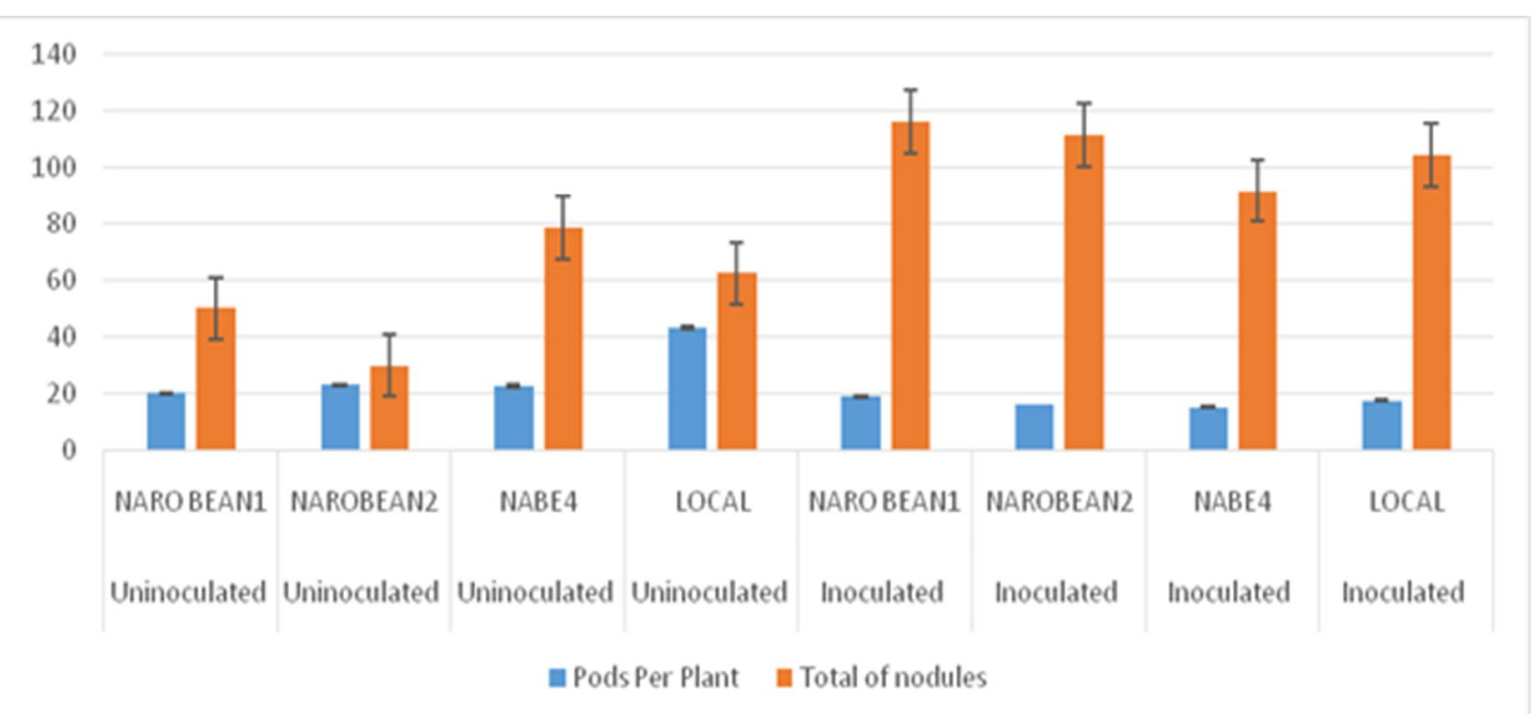

Fig. 5: Number of pods per plant and total number of nodules per plant as influenced by Rhizobium leguminosarum bv phaseoli inoculation

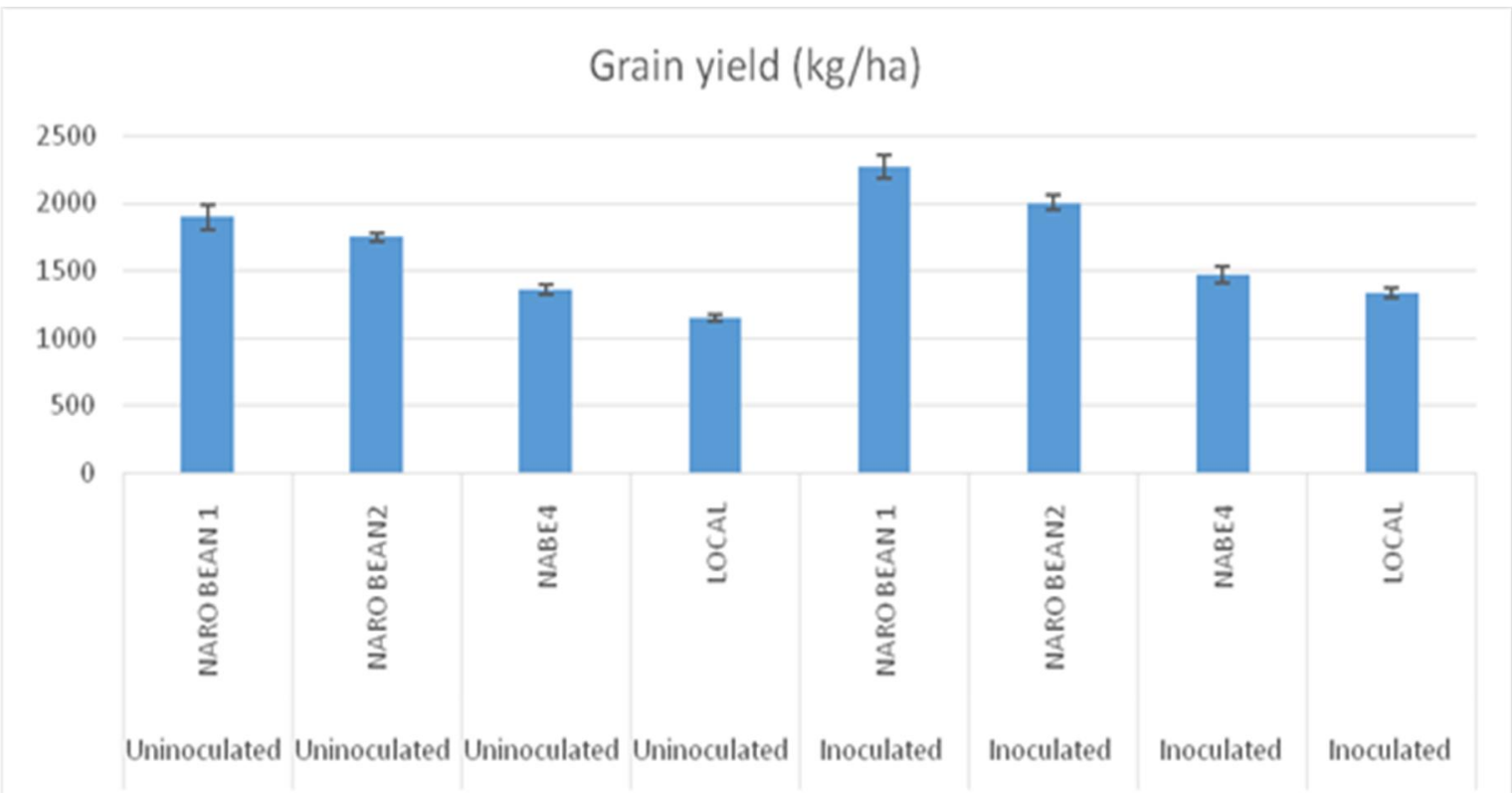

Fig. 6: Grain yield (kg/ha) as influenced by Rhizobium leguminosarum bv phaseoli inoculation

\section{Discussion}

The major constraint limiting crop productivity is low fertility of soil (Diatta et al., 2020). The success of leguminous crops depends on their ability to form efficient Nitrogen-fixing symbiosis with root nodule rhizobia. Rhizobia associated with legumes can be used to improve crop productivity at a very low cost (Zahran, 2009). Inoculation is essential where nitrogen fixing bacteria is low to enhance the effective population of rhizobium in the rhizhosphere of the crop (Bhattacharjee et al., 2008). Many workers have indicated the necessity of legume inoculation with effective and efficient rhizobial strains (Mekhemar et al., 2007 Badawi et al., 2011). It is clear that, plants inoculated with Rhizobiaceae yield more than uninoculated plants.

Our results show a positive effect of inoculating soybean and common beans with Bradyrhizobium japanicum and Rhizobium leguminosarum bv phaseoli respectively. The increased soybean and bean yield in all inoculated treatments might be attributed to the promoted vegetative growth owing to the availability of nitrogen via diazotrophy. The substantial increase in both grain 
legume yield in response to inoculation compared with the control is in line with previous reports (Otieno et al., 2009; Denton and Peoples 2010; Njira et al., 2013 and Mabrouk et al., 2018).

There was no significant difference in number of nodules following inoculation with Bradyrhizobium japonicum compared to the un-inoculated plants. This could be attributed to the presence of a high population of native rhizobia in the soil enabling nodulation in the uninoculated plots. However, significant number of nodules was observed following inoculation with Rhizobium leguminosarum phaseoli compared with the un-inoculated plots, implying that there was low population of native Rhizobium leguminosarum phaseoli compared to Bradyrhizobium japonicum in the soil (Pulver et al., 1982)

There was significant difference observed in number of pods for both soybeans and beans in uninoculated plots compared to inoculated plots. The grain yield was significantly higher in inoculated plots of both soybeans and beans compared to the un-inoculated plots. This could be attributed to the presence of nodules that were effective at fixing nitrogen. The results also indicate that both the improved soybean and beans genotypes respond differently to inoculation. Inoculation significantly increased yield in selected improved varieties in soybean and beans on average by $22.3 \%$ and $15 \%$, respectively. In soybean MAKSOY $1 \mathrm{~N}$, MAKSOY $5 \mathrm{~N}$, MAKSOY $3 \mathrm{~N}$ and LOCAL varieties were respectively improved by $14.13 \%, 23.33 \%, 64.40 \%$ and $42.8 \%$ compared to the non-inoculated controls. In beans NARO BEAN1, NARO BEAN2, NABE4 and LOCAL were respectively improved by $19.71 \%, 14.50 \%, 7.84 \%$ and $16.27 \%$ compared to the non-inoculated controls.

\section{Conclusion}

It can be concluded that exploitation of efficient MAK-BIO-FIXER inoculum containing Bradyrhizobium japonicum and Rhizobium leguminosarum bv phaseoli improved the nodulation process and grain legume yield for selected improved genotypes in soybean and beans by an average of $22 \%$ and $15 \%$, respectively.

\section{Recommendation}

Among the soybean varieties maksoy $3 \mathrm{~N}$ had the best response in terms of yield increase due to Bradyrhizobium japonicum inoculation followed by the local check and in beans NARO BEAN 1, had the best response followed by the local check. Hence, Bradyrhizobium japonicum and Rhizobium leguminosarum bv phaseoli inoculum are efficient for improving yields among improved varieties for soybean and beans respectively. The farmers saved seeds (local check) also responded positively to use of inoculant. The low cost of this inoculant makes it affordable to the local farmers, this can be a great opportunity to improve on farm yield.

\section{Limitations}

In this study the amount of nitrogen fixed by MAK-BIO-FIXER inoculum was not assessed. The estimation of nitrogenase activity, as well as the dry weights of the root nodules and the nitrogen content of the plant were not evaluated to test the efficiency of the tested bacterial inocula.

\section{Acknowledgements}

This study was implemented by Ngetta Zonal Agricultural Research and Development Institute under the National Agricultural Research Organization. Special thanks to the Government of Uganda with a grant from ASAP (Adaptation for smallholder Agricultural Program) and a loan from IFAD through the Project for Restoration of Livelihood in the Northern Region for funding this study. We are grateful to farmers in Kitgum, Lamwo, Omoro, Agago, Amuru and Lira from whom we collected the data

\section{References}

Amarger, N., 2001. Rhizobia in the Field. Advances in Agronomy (Ed. D.L. Sparks), Academic Press. 73: $109-167$. 
Badawi, F.Sh.F., A.M.M. Biomy and A.H. Desoky, 2011. Peanut plant growth and yield as influenced by co-inoculation with Bradyrhizobium and some rhizo-microorganisms under sandy loam soil conditions. Annals Agric. Sci., Ain Shams Univ., 56: 17-25.

Bhattacharjee, R.B., A. Singh, and S.N. Mukhopadhyay, 2008. Use of nitrogen-fixing bacteria as biofertiliser for non-legumes: prospects and challenges. Applied microbiology and Biotechnology, 80(2): 199-209.

Denton, M.D. and M.B. Peoples, 2010. The importance of inoculant type or application rate for nitrogen fixation by grain legumes in cropping systems of south-eastern Australia. "Food Security from Sustainable Agriculture". H. Dove and R.A. Culvenor (Eds), Proceedings of $15^{\text {th }}$ Agronomy Conf., 15-18 November, Lincoln, New Zealand.

Diatta, A.A., J.H. Fike, M.L. Battaglia, J.M. Galbraith, and M.B. Baig, 2020. Effects of biochar on soil fertility and crop productivity in arid regions: a review. Arabian Journal of Geosciences, 13(14), 1-17. https://doi.org/10.1007/s12517-020-05586-2

FAO., 2016. Fertilizer consumption (kilograms per hectare of arable land)| Data. https://data.worldbank.org/indicator/AG.CON.FERT.ZS

Giller, K.E., M. Corbeels, J. Nyamangara, B. Triomphe, F. Affholder, E. Scopel, and P. Tittonell, 2011. A research agenda to explore the role of conservation agriculture in African smallholder farming systems. Field Crops Res., 124: 468 - 472.

Hungria, M., A.S. Nakatani, R.A. Souza, F.B. Sei, L.M. de Oliveira Chueire, and C.A. Arias, 2015. Impact of the ahas transgene for herbicides resistance on biological nitrogen fixation and yield of soybean. Transgenic research, 24(1): 155-165.

Hungria, M. and T.R.J. Bohrer, 2000. Variability of nodulation and dinitrogen fixation capacity among soybean cultivars. Biology and Fertility of Soil, 31: 45-52.

Jensen, E.S. and H. Hauggaard, 2003. How can increased use of biological $\mathrm{N}_{2}$-fixation in agriculture benefit the environment?. Plant and Soil, 252: 177-186.

Joint, F.A.O., 1998. Improving yield and nitrogen fixation of grain legumes in the tropics and subtropics of Asia. Results of a co-ordinated research programme. Joint FAO/IAEA Division of Nuclear Techniques in Food and Agriculture.

Kanianska, R., 2016. Agriculture and Its Impact on Land-Use, Environment, and Ecosystem Services. Landscape Ecology - The Influences of Land Use and Anthropogenic Impacts of Landscape Creation. https://doi.org/10.5772/63719

Kumakech, A., A. Acipa, F. Doi, and G.A. Maiteki, 2014. Efficacy of rehabilitation methods on citrus canker disease in northern Uganda. African Crop Science Journal, 22(2): 117-121.

Mabrouk, Y., I. Hemissi, I.B. Salem, S. Mejri, M. Saidi, and O. Belhadj, 2018. "Potential of Rhizobia in Improving Nitrogen Fixation and Yields of Legumes". In E. C. Rigobelo (Ed.), Symbiosis. InTech. https://doi.org/10.5772/intechopen.73495

Mekhemar, G.A.A., F.M. Ismail, F.Sh.F. Badawi and B.A.A. Kandil, 2007. Response of peanut (Arachis hypogaea L.) to co-inoculation with Bradyrhizobium spp. and phosphate dissolving bacteria under different levels of phosphorus fertilization in sandy soils. Agric. Res. J., Suez Canal Univ., 7: 1-8.

Ndakidemi, P.A., F.D. Dakora, E.M. Nkonya, D. Ringo, and H. Mansoor, 2006. Yield and economic benefits of common bean (Phaseolus vulgaris L.) and soybean (Glycine max L. Merr.) inoculation in northern Tanzania. Aust. J. Exp. Agric., 46: 571-577.

Njira, K.O.W., P.C. Nalivata, G.Y. Kanyama-Phiri, and M.W. Lowole, 2013. An assessment for the need of soybean inoculation with Bradyrhizobium japonicum in some sites of Kasungu district, central Malawi. Inter. J. Curr. Microbiol. and Appl. Sci., 8: 60-72.

Otieno, P.E., J.W. Muthomi, G.N. Chemining'wa, and J.H. Nderitu, 2009. Effect of rhizobia inoculation, farm yard manure and nitrogen fertilizer on nodulation and yield of food grain legumes. Journal of Biological Sciences

PRELNOR., 2017. Summary report on commodity baseline survey. http://prelnor.molg.go.ug/wpcontent/uploads/2017/05/PRELNOR-REPORT.pdr_.pdf

Pulver, E.L., E. Kueneman, and R. Rao, 1982. Identification of promiscuous nodulating soybeans efficient in $\mathrm{N} 2$ fixation. 
Snapp, S., G. Kanyama-Phiri, B. Kamanga, R. Gilbert, and K. Wellard, 2002. Farmer and researcher partnerships in Malawi: developing soil fertility technologies for the near-term and far-term. Experimental Agriculture; Cambridge University Press. https:// doi.org/10 .1017/ S0014479702000443.

Snedecor, G.A. and W.G. Cochran, 1980. "Statistical Methods". $7^{\text {th }}$ Ed., Iowa State Univ. Press, Am., USA, 255-269.

Tittonell, P. and K.E. Giller, 2013. When yield gaps are poverty traps: The paradigm of ecological intensification in African smallholder agriculture. Field Crops Res., 143: 76 - 90. https://doi.org/10.1016/j.fcr.2012.10.007.

Vidigal, P., M.M. Romeiras, and F. Monteiro, 2019. Crops Diversification and the Role of Orphan Legumes to Improve the Sub-Saharan Africa Farming Systems. Sustainable Crop Production. https://doi.org/10.5772/intechopen.88076

Zahran, H.H., 1999. Rhizobium-legume symbiosis and nitrogen fixation under severe conditions and in an arid climate. Microbiol. Mol. Biology Rev., 63(4): 968. https://doi.org/10.1128/MMBR.63.4.968-989.

Zahran, H.H., 2009. Enhancement of rhizobia-legumes symbioses and nitrogen fixation for crops productivity improvement. In Microbial strategies for crop improvement (pp. 227-254). Springer, Berlin, Heidelberg. https://doi.org/10.1007/978-3-642-01979-1_11. 